DEPÓSITO LEGAL ZU2020000153

Esta publicación científica en formato digital

es continuidad de la revista impresa

ISSN 0041-8811

E-ISSN 2665-0428

Revista

de la

Universidad

del Tunlia

Fundada en 1947

por el Dr. Jesús Emrique Lossada

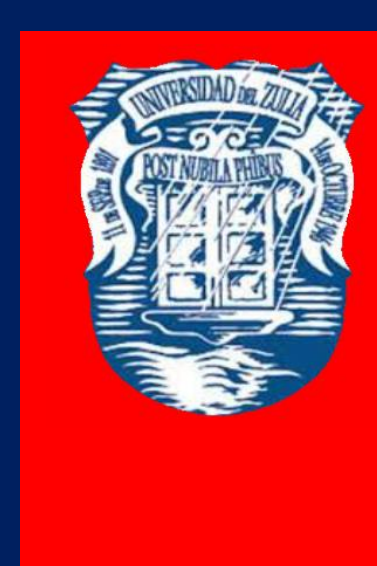

Ciencias

Sociales

y Arte

Aกัต 11 No 31

Septiembre - Diciembre 2021

Tercera ípoca

Maracailbo-Venezuela 
REVISTA DE LA UNIVERSIDAD DEL ZULIA. 3época. Año $11 \mathrm{~N}^{\circ}$ 31, 2020

Natalia A. Tsareva \& Sofiya Yu. Omelyanenko /// Remote work: development of employee ...131-140

DOI: http://dx.doi.org/10.46925//rdluz.31.10

\title{
Remote work: development of employee digital competence
}

\author{
Natalia A. Tsareva* \\ Sofiya Yu. Omelyanenko**
}

ABSTRACT

Remote work in the context of global computerization of all work processes is an integral part of the functioning of companies. With the growing number of employees working remotely, it is important to conduct correctly the adaptation period for the transition to a new communication format for both employees and the candidates for a vacancy. The aim of this article is to survey a number of classifications of employee digital competencies proposed by scientists. The study was carried out on the use of tools by employees in a stressed work format: it was revealed that when employees possess the skills to use digital tools for remote work, company managers do not use these skills when building communications and working in new conditions. The analysis of the resume base is given in order to determine the formation of digital competence among the candidates. A toolkit has been developed to determine the formation of digital competence and assess the effectiveness of an employee at remote work.

KEYWORDS: personnel management, personnel processes, remote work, distance learning, adaptation, remote employment tools.

${ }^{*}$ Candidate of political sciences, Associate professor of the department «Economic and Management», Vladivostok State University of Economics and Service 690014, Russia, Vladivostok, st. Gogolya, 4l. ORCID: https://orcid.org/0000-0002-0388-2526. E-mail: natsareva@mail.ru

${ }^{* *}$ Bachelor, Vladivostok State University of Economics and Service, 690014, Russia, Vladivostok, st. Gogolya, 4l. ORCID: https://orcid.org/0000-0002-8031-3976. E-mail: natsareva@mail.ru 


\section{Trabajo a distancia: desarrollo de la competencia digital de los empleados}

RESUMEN

El trabajo a distancia en el contexto de la informatización global de todos los procesos de trabajo es parte integral del funcionamiento de las empresas. Con el creciente número de empleados que trabajan de forma remota, es importante realizar correctamente el período de adaptación para la transición a un nuevo formato de comunicación tanto para los empleados como para los candidatos a una vacante. El objetivo de este artículo es examinar una serie de clasificaciones de competencias digitales de los empleados propuestas por científicos. El estudio se realizó sobre el uso de herramientas por parte de los empleados en un formato de trabajo estresado: se reveló que cuando los empleados poseen las habilidades para usar herramientas digitales para el trabajo remoto, los gerentes de la empresa no utilizan estas habilidades al construir comunicaciones y trabajar en nuevas condiciones. El análisis de la base de currículum se da para determinar la formación de competencia digital entre los candidatos. Se ha desarrollado un conjunto de herramientas para determinar la formación de la competencia digital y evaluar la eficacia de un empleado en el trabajo remoto.

PALABRAS CLAVE: gestión de personal, procesos de personal, trabajo a distancia, formación a distancia, adaptación, herramientas de empleo a distancia.

\section{Introduction}

The events taking place in the world today have influenced the economy, the form of labor relations and the implementation of the functional duties of employees. Elementary issues of practice and norms in the most diverse spheres of life will cause a lot of discussion, undergo changes, some will disappear forever. At the moment, the transition to a remote format of work is the most relevant topic of the current year and subsequent years. World economic processes in the context of a pandemic have already affected the business of many companies, primarily international ones or the companies which have numerous contacts with foreign partners. The number of business trips has been limited, the supply of products from some countries has been reduced to a minimum or stopped altogether, and many companies are shutting down. The trends that are now taking place in the economic system will cause unemployment increase in a number of sectors of the economy (Parra Contreras, 2020), primarily those related to the service sector, tourism, public catering, the hotel sector and the entertainment sector. In the current economic conditions, the growth of 
REVISTA DE LA UNIVERSIDAD DEL ZULIA. 3é época. Año 11 N 31, 2020

Natalia A. Tsareva \& Sofiya Yu. Omelyanenko /// Remote work: development of employee ...131-140

DOI: http://dx.doi.org/10.46925//rdluz.31.10

unemployment can be avoided by bringing the functional responsibilities of workers into the format of remote work. The Flexjobs survey of 2017 found that the workers prefer telecommuting because it provides more personal benefits: work-life balance, flexibility, job value, autonomy, freedom, and independence (Reynolds, 2017). Along with the clear benefits of telecommuting, a number of challenges arise. One of them is the formation of personal operational digital skills necessary for an employee to interact with the purpose of work problem solution using information technology. In modern conditions, the success of a company depends on how competent its employees are in digital communications. More and more professions are influenced by the general trend of remote employment, including the financial sector, sales, education, design, media, HR, etc. But a company has never faced the problem of rapid widespread implementation of remote work in a short period of time so globally. In this regard, the organization of teleworking raises many difficulties. The main point of this article is to overview various characterizations of representative advanced skills proposed by researchers.

\section{Methodology}

This study was conducted on the use of tools by employees in the form of pressured work. The method used is based on a review of past research in this field and analysis and summarizing the views of past researchers

\section{Theoretical Bases}

Remote work, online grouping, and remote collaboration have become much more common in recent years, and especially in recent months. According to the Labor Code of the Russian Federation (Article 312.1), distance employment means "the performance of a labor function determined by an employment contract outside the employer's location, directly or indirectly under the control of the employer, provided that public information and telecommunication networks are used to perform this labor function" (RF LC). To perform a labor function outside of the objects that are under the direct or indirect control of the company, in order to receive tasks and send the result, an employee needs the Internet. A precondition for an effective knowledge transfer process in a virtual environment is the establishment of effective electronic communication between individuals. The study of 
REVISTA DE LA UNIVERSIDAD DEL ZULIA. 3é época. Año 11 N 31, 2020

Natalia A. Tsareva \& Sofiya Yu. Omelyanenko /// Remote work: development of employee ...131-140

DOI: http://dx.doi.org/10.46925//rdluz.31.10

effective remote interaction problems was carried out by various authors in the analysis of the operational-digital environment and the practices of its use in remote work (Watanuki et al., 2015, Sukhomlin V.A., 2017, Klescheva N.A. 2011, 2013). Particular attention was paid to the formed professional knowledge, skills and abilities necessary to perform operational digital work. Skills are considered as the ability of an employee to ensure the implementation of a specific professional activity (Nedoluzhko, 2016). Digital competence is defined as the ability to search, analyze, select, process, and transmit the necessary information independently using communicative information technologies (Zamara, 2014).

Wang Y. and Haggerty N. proposed the following classification of personal operational digital competencies that enable workers to interact and communicate in a digital environment:

1. operational digital skills in the media space, focused on the productive ability to use technology in various situations,

2. operational digital skills in the social sphere, represent an important element of cohesion and mutual understanding increase between people, focused on the formation of skills used to build social relations,

3. operational-digital skill of productivity control, self-efficacy, which includes discipline when working on a computer and control of self-efficacy when performing remote work (Wang, Haggerty, 2009).

The level of an employee's operational-digital competency development is determined by the result of previous experience of remote work and the experience of his daily life in a digital environment (Wang, Haggerty, 2011).

V.A. Sukhomlin, E.V. Zubareva and Yakushin A.V. offer the following classification of digital skills:

1. Shared digital skills enable workers from a wide range of professions to use information technology in their daily work.

2. Complementary skills - the skills for performing specific tasks related to the use of information technology in the workplace: using social networks to communicate with colleagues and clients, promoting a brand of products on e-commerce platforms, analyzing big data, business planning etc. 
REVISTA DE LA UNIVERSIDAD DEL ZULIA. 3época. Año 11 N 31, 2020

Natalia A. Tsareva \& Sofiya Yu. Omelyanenko /// Remote work: development of employee ...131-140

DOI: http://dx.doi.org/10.46925//rdluz.31.10

3. Professional digital skills are the skills in system engineering, programming, application development, data and network management, etc.

4. Problem-oriented digital skills - the skills of experts who develop and use specialized problem-oriented platforms, applications, and software packages (Sukhomlin, 2017)

In the day-to-day implementation of his functional duties, an employee must have both general and complementary digital skills that allow him to carry out his functional duties outside the employer's location. Before introduction the practice of remote work and working on changing the course of personnel processes, it is necessary to determine all the pros and cons of this work format (Arnaut, 2018). Here are some of the arguments "for" the introduction of remote work (by the employer):

saving on material and technical equipment of workplaces;

the geography of staff recruitment is expanding significantly;

the costs of the wage fund are reduced;

flexibility to external factors (quarantine regime, bad weather conditions, illness of an employee's child);

reduction of problematic inspections by the State supervision and control over labor protection;

reduction of required premise area, and rent (Varkulevich, 2018, Ivanova, 2018).

Here are the arguments "for" the introduction of remote work (on the part of the employee):

saving time and money;

a flexible schedule that allows you to combine several cases;

work at your own pace;

more time for family/friends;

high mobility;

adaptation of a number of management processes (Hislop D., et al., 2008).

The arguments "against": transition of HR processes to "remote work"; reduced communication among employees; a large number of remote workers require the creation of a technical support center in the company; additional administrative costs; self-control problems (Bloom, N., 2009). 
REVISTA DE LA UNIVERSIDAD DEL ZULIA. 3época. Año $11 \mathrm{~N}^{\circ}$ 31, 2020

Natalia A. Tsareva \& Sofiya Yu. Omelyanenko /// Remote work: development of employee ...131-140

DOI: http://dx.doi.org/10.46925//rdluz.31.10

The task of the company's management is not only to assess the level of digital competence formation among employees, but also to contribute to the formation of digital competence of all employees.

\section{Results and discussion}

As the part of the study, the survey of Primorsky Krai company employees was conducted performing their functionality in remote work conditions using docs.google.com/forms. Out of 177 respondents, $77.6 \%$ belong to the age group of $22-45$ year olds. The respondents' activities are related to engineering (37.3\%), human resources management (25.4\%), management (11.9\%), administration, analytics, online sales, and jurisprudence. When they choose the advantages of telecommuting, the majority determined for themselves time savings on the road (67.8\%), as well as the opportunity to combine work and personal affairs (55.9\%). The disadvantages were the following (multiple choice):

difficulty of concentration on work - 39\%,

lack of company affair awareness - $40.7 \%$,

many distractions - $45.8 \%$,

lack of communication with colleagues $-52.5 \%$, while constant communication with colleagues (several times a day) was noted by $62.7 \%$ of the respondents. Isolation and the ability to communicate only on work issues reduces the feeling of commitment to the company (Yakimova, 2018).

When they perform their functional duties, employees prefer to use WhatsApp (89.8\%), Email (49.2\%), Skype (27.1\%) for communication. For time tracking - Bitrix 24, Upwork, Jira, Rescue Time, Toggi, and Redmine. To keep track of the completion of tasks notes on the phone, the traditional way (pen and notebook), email, a few employees use Jira, Trello, Asana, Redmine, and Bitrix 24. When assessing the level of proficiency in programs (Bitrix 24, Upwork, Jira, RescueTime, Toggi, Redmine, Trello, Asana) from 30.5\% to 45.7\% of respondents indicated the levels of an advanced and confident user. The respondents assessed job satisfaction and its effectiveness depending on the format: does not depend (49.2\%); higher when I work full-time (37.3\%) and higher when I work remotely (11.9\%). The study showed that, despite knowledge of remote employment tools, employees do not use them in their work everywhere. With all the advantages of telecommuting, only 11.9\% noted the increase of their effectiveness in teleworking. 
REVISTA DE LA UNIVERSIDAD DEL ZULIA. 3época. Año $11 \mathrm{~N}^{\circ}$ 31, 2020

Natalia A. Tsareva \& Sofiya Yu. Omelyanenko /// Remote work: development of employee ...131-140

DOI: http://dx.doi.org/10.46925//rdluz.31.10

The successful functioning of a company is impossible without new employee attraction (Terentyeva, 2017). To study the formation of digital competence among the candidates for a vacancy, they performed the analysis of the available resumes on the Farpost and HeadHunter websites. Studying the questionnaires presented on the sites, the selection of applicants was carried out according to such criteria as the presence of work experience remotely, the possibility of remote work, age and field of activity. The results of the study showed that about $40 \%$ of job seekers at the age of 18 - 45 had previous experience of remote work. Mostly remote work is found in such areas as content management, marketing, design, web development, sales, and management. Thus, both company employees and the candidates for vacancies in many areas of activity are ready to switch to remote work.

Before organizing remote work, you should analyze the specifics of the work of each department or employee and understand whether it will be possible to organize remote work, how often an employee will have to solve issues that cannot be resolved in an online format, identify responsible persons from each department who have experience in software components. The developed tool for determining the effectiveness of an employee when working remotely will make it possible to assess the formation of digital competence and the possibility of transferring a certain department or an employee to remote work (Table 1).

After analyzing the responses of employees working remotely, the manager will have the opportunity of remote work implementation at an early stage to prepare for adaptation qualitatively, identify the key points that are worth paying attention to, or that need to be replaced, modernized, and created (Simikyan, 2016, Adaptation, 2020). Remote work should be organized by training employees on basic software products, their components, etc. It is necessary to develop a distance learning course, and instructions for users. Formats for employee training must be effective remotely, that is, via the Internet. Use of webinars with feedback; online courses; distance courses recorded; mobile learning; tests; infographics; personal conversations with an employee via Skype, Google meet, etc. will allow you to form digital competence quickly among employees. Monitoring the execution of the work plan of employees and the entry into positions of new ones is possible using Redmine, Megaplan, Skillbox, Veb.ru, etc. by including technical support numbers or a list of frequently asked questions and answers. Another task of managers is to ensure the flow of work processes in 
REVISTA DE LA UNIVERSIDAD DEL ZULIA. $3^{a}$ época. Año 11 N 31, 2020

Natalia A. Tsareva \& Sofiya Yu. Omelyanenko /// Remote work: development of employee ...131-140

DOI: $\underline{\text { http://dx.doi.org/10.46925//rdluz.31.10 }}$

such a way that an employee feels his involvement in the company, shares the company mission and its values.

Table 1. Analysis of employee performance with remote employment tools

\begin{tabular}{|c|c|c|c|}
\hline Point & $\begin{array}{l}\text { Difficulties } \\
\text { at work }\end{array}$ & $\begin{array}{l}\text { Problem } \\
\text { solution } \\
\text { way }\end{array}$ & $\begin{array}{l}\text { Time to } \\
\text { resolve } \\
\text { the } \\
\text { issue }\end{array}$ \\
\hline
\end{tabular}

Technical equipment

Computer, keyboard, mouse, printer, scanner, telephone, etc.

\section{Information databases / organization data}

Google / Yandex cloud, Remote hard drive, Consultant, Garant, etc.

\section{Work programs}

Excel, Word, One note, Power Point, Publisher, lC, etc.

\section{Document flow / email}

RSMED, e-mail, Google, Yandex, Inbox, etc.

\section{Video communication, chat}

Skype, Zoom, Viber, WhatSapp, etc.

\section{Goal setting}

Trello, Jira, Redmine, Asana, etc.

\section{Reports}

Excel Word, One note, Power Point, Publisher, etc.

\section{Working hours}

Hubstaff, Redmine, Битрикс 24, Upwork, Jira, Rescue

Time, Toggi, etc.

\section{Onboarding and training of remote employees}

CRM-system, Google, Hangouts, Google Drive, Google

Docs, etc. 
REVISTA DE LA UNIVERSIDAD DEL ZULIA. 3é época. Año $11 \mathrm{~N}^{\circ}$ 31, 2020

Natalia A. Tsareva \& Sofiya Yu. Omelyanenko /// Remote work: development of employee ...131-140

DOI: http://dx.doi.org/10.46925//rdluz.31.10

Conclusion

The main function of management in the process of moving to a remote format is to provide a basis for effective communication and information transfer on work issues. Individual digital competence as the degree of knowledge, skills and abilities that a person possesses to work and communicate in a digital environment for performing collaborative work can be formed through various tools. The employees with a formed digital competence demonstrate increased efficiency performing their functional duties in comparison with the persons who have not formed this competence. The high level of digital competence development affects not only individual work efficiency, but also individual job satisfaction.

The introduction of technologies and practices of remote work will allow rationalizing the use of office interiors, labor force, working and non-working hours. One step ahead will be those companies that already understand the importance of moving faceto-face work to the online format and realize how much people value their time. The employers who have already begun to move in this direction will have an undoubted advantage in modern difficult conditions.

\section{References}

Adaptation of remote workers: how to involve employees in the process (2020) [Electronic resource] - Access mode: https://www.hr-director.ru/article/67652-adaptatsiyadistantsionnyh-rabotnikov-20-m4

Arnaut M.N., Mitrofanova T.V. (2018). Personnel management: essence, approaches to interpretation, models. Azimuth of scientific research: economics and administration. V.7. No. 1 (22) pp. 22-25.

Bloom, N., Kretschmer, T., \& John Van Reenen, J.V. (2009). Work-life Balance, Management Practices and Productivity, in International Differences in the Business Practice and Productivity of Firms, Richard Freeman, and Kathryn Shaw, eds. (Chicago: University of Chicago Press, 2009).

Hislop D., Axtell C., and Daniels K. (2008). The Challenge of Remote Working. The Oxford Handbook of Personnel Psychology. DOI:10.1093/oxfordhb/9780199234738.001.0001

Ivanova O.E. (2018). Methodological foundations of the concept of human resource management. Azimuth of scientific research: economics and administration. V.7. No. 3 (24) pp.109-112. 
REVISTA DE LA UNIVERSIDAD DEL ZULIA. 3é época. Año 11 N 31, 2020

Natalia A. Tsareva \& Sofiya Yu. Omelyanenko /// Remote work: development of employee ...131-140

DOI: http://dx.doi.org/10.46925//rdluz.31.10

Klescheva N.A., Petruk G.V. (2013) Systematic process organization of forming professionally important qualities of future specialists. Pacific Science Review. V. 15. No. 2. pp. 85-89.

Kleshcheva N.A., Petruk G.V. (2011) Development of pedagogical support of the process of forming professional-important qualities of an economist-manager. Pacific Science Review. V. 13. No 4. pp. 281-283.

Labor Code of the Russian Federation (December 30, 2001), No. 197-FL (2001). Access mode: Reference legal system "ConsultantPlus" http://www.consultant.ru/cons

Nedoluzhko, O.V., Varkulevich, T.V., Baturina, O.A. (2016) Evolution of individual's intellect as basis for forming intellectual capital of organization. Journal of Advanced Research in Law and Economics, 7 (2), pp. 332-340.

Parra Contreras, R. (2020). Una perspectiva del mundo que se nos avecina, Revista de la Universidad del Zulia, 11 (29), 3-5. DOI: http://dx.doi.org/10.46925/rdluz.29.01

Reynolds, Brie Weiler (2017) 2017 annual survey finds workers are more productive at home, and more. Retrieved from https://www.flexjobs.com/blog/post/productive-working-remotely-topcompanies-hiring/

Simikyan N.A., Pererva O.L. (2016). Assessment of personnel management effectiveness. Azimuth of scientific research: economics and administration. V.5. No. 4 (17) pp. 336-338.

Sukhomlin V.A., Zubareva E.V., Yakushin A.V. (2017) Methodological aspects of the concept of digital skills. Modern information technologies and IT education. Volume 13 No. 2. p.

Terentyeva, T.V., Korneyko, O.V. (2017) New approaches to interpretation of entrepreneurship in context of modern development of the Russian economy. Espacios, 38 (62), 33.

Varkulevich T.V., Beloglazova V.A. (2018) Organizational and methodological foundations of effective personnel policy of the state university. Azimuth of scientific research: economics and administration. V.7. № 2(23). 43-47.

Wang, Y. \& Haggerty, N. (2009) Knowledge Transfer in Virtual Settings: The Role of Individual Virtual Competency. Information Systems Journal, 19:571-593.

Wang, Y. \& Haggerty, N. (2011) Individual Virtual Competence and Its Influence on Work Outcomes[J]. Journal of Management Information Systems, 27(4): 299-333.

Watanuki H.M., Laurindo F.J.B., Moraes R. de O. (2015). Development of Individual Virtual Competences: Practices in Brazilian Companies. RISUS - Journal on Innovation and Sustainability, São Paulo, v. 6, n.2, pp. 34-45.

Yakimova Z.V., Pushkina A.S. (2018). Dynamics of personnel involvement level depending on the length of service in the organization. Azimuth of scientific research: economics and administration. V.7. No. 1 (22) pp. 283-286.

Zamara E.V. (2014). Information and technological competence of an individual in the conditions of modern secondary vocational education. Azimuth of scientific research: pedagogy and psychology. 2014. No. 1. pp. 29-31. 